\title{
(Re)Presenting the role of iconography in African Christian liturgy: A case study of Serima Mission in the Catholic Diocese of Gweru in Zimbabwe (1948-2021)
}

\begin{tabular}{|c|c|}
\hline \multicolumn{2}{|c|}{$\begin{array}{l}\text { Authors: } \\
\text { Misheck Mudyiwa }^{1} \text { (1) } \\
\text { Sekgothe Mokgoatšana }^{1}\end{array}$} \\
\hline \multicolumn{2}{|c|}{ 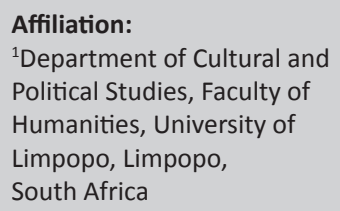 } \\
\hline \multicolumn{2}{|c|}{$\begin{array}{l}\text { Corresponding author: } \\
\text { Sekgothe Mokgoatšana, } \\
\text { sekgothe@gmail.com }\end{array}$} \\
\hline \multicolumn{2}{|c|}{$\begin{array}{l}\text { Dates: } \\
\text { Received: } 10 \text { May } 2021 \\
\text { Accepted: } 03 \text { July } 2021 \\
\text { Published: } 23 \text { Nov. } 2021\end{array}$} \\
\hline \multicolumn{2}{|c|}{$\begin{array}{l}\text { How to cite this article: } \\
\text { Mudyiwa, M. \& } \\
\text { Mokgoatšana, S., 2021, } \\
\text { '(Re)Presenting the role } \\
\text { of iconography in } \\
\text { African Christian liturgy: } \\
\text { A case study of Serima } \\
\text { Mission in the Catholic } \\
\text { Diocese of Gweru in } \\
\text { Zimbabwe (1948-2021)', } \\
\text { HTS Teologiese Studies/ } \\
\text { Theological Studies } \\
\text { 77(2), a6829. https://doi. } \\
\text { org/10.4102/hts.v77i2.6829 }\end{array}$} \\
\hline \multicolumn{2}{|c|}{$\begin{array}{l}\text { Copyright: } \\
\text { (c) 2021. The Authors. } \\
\text { Licensee: AOSIS. This work } \\
\text { is licensed under the } \\
\text { Creative Commons } \\
\text { Attribution License. }\end{array}$} \\
\hline \multicolumn{2}{|l|}{ Read online: } \\
\hline 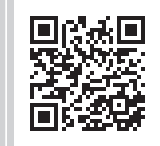 & $\begin{array}{l}\text { Scan this QR } \\
\text { code with your } \\
\text { Smart phone or } \\
\text { mobile device } \\
\text { to read online. }\end{array}$ \\
\hline
\end{tabular}

Authors:

Misheck Mudyiwa ${ }^{1}$ (I)

\section{Affiliation:}

${ }^{1}$ Department of Cultural and Limpopo, Limpopo, Africa Sekgothe Mokgoatšana, Dates:

Received: 10 May 2021 Accepted: 03 July 2021 Published: 23 Nov. 202

ow to cite this article: Mokgoatšana, S., 2021 '(Re)Presenting the role A case study of Serima Mission in the Catholic Zimbabwe (1948-2021)', HTS Teologiese Studies/ togical Studies 77(2), a6829. https://doi

Licensee: AOSIS. This work is licensed under the Creative Commons Attribution License.
This article examines the role of iconography in African Christian liturgy with a particular focus on Serima Mission in the now Catholic Diocese of Gweru in Central Zimbabwe. Of all Catholic missions in Zimbabwe, Serima Mission is perhaps the most popular in iconography with innumerable sets of wood and stone carvings portraying mostly religious scenes based on African designs and patterns. The atmosphere at Serima Mission, particularly the church interior, presents an expression of the power of African art, visual language, summation of the Catholic faith, and the otherness and transcendental nature of the omniscient, omnipotent, and omnibenevolent Christian God. This article firstly presents the history and impact of Serima African School of iconography under the tutelage of Fr John Groeber. Furthermore, it explores the role of iconography in African Christian liturgy on the Roman Catholic Church. The article critically examines iconography in African religion and spirituality, Sacred Scripture and celebrated traditional Christian practices. This article argues that, whilst religious symbols are on the physical realm, in reality, they symbolise and represent the metaphysical and transcendental realities. Although, they are often associated with religious formalism, exaggerated spirituality, and idol worship, icons and images have conveyed unprecedented allegorical messages across time and cultures.

Contribution: This article expands the studies of iconography and semiology in theological landscapes and texts, allowing for the recognition and repositioning of art interpretation from an African experience.

Keywords: iconography; Serima Mission; Zimbabwe; African liturgy; metaphysical realities; semiotics; African semiology; symbolism.

\section{Introduction}

Religious symbolism is essential to all religions of the world and is perhaps as old as religion itself. For centuries, religious symbols, art, and images have been used to convey concepts pertaining to humanity's relationship with the hierophany and the 'awe-inspiring Ganz Andere' (Eliade 1957:9) or 'that which people (the $I-W e$ ) appropriately respond to as being of unrestricted value for them' (Cox 1992:15). Thus, from the oldest to the youngest religion of the world, natural or revealed, the visibility of iconic representation cannot be overstated. Whilst, on the one hand, such iconic representations are tailor-made to represent a specific religion, like in the case of Judaism (Chai symbol with the Star of David), Buddhism (Dharma Wheel), Christianity (Cross), and Islam (Crescent and Star), on the other hand, countless sets of murals represent a specific concept or concepts, doctrines and moral lessons peculiar to each particular religion. In Christian (particularly Catholic) settings, iconic representations of concepts such as the Nativity, Last Supper, Passion of Christ, Resurrection, Ascension, Pentecost, and saints, among many others have not been lacking for centuries. Because in the ordinary course of life devotees do not come into direct contact with the divinity, symbols, gestures, visible objects, signs, and words have always symbolised and represented the metaphysical and transcendental realities (Sarpong 1985:4). These are regarded as a mode of communicating with the unseen supernatural.

These icons represent the tangible, and concrete experience often used to contemplate the existence of the figurative and abstract reality. For decades, African Christian liturgy has been occupied by

Note: Special Collection: Social Memory Studies, sub-edited by Christina Landman (University of South Africa) and Sekgothe Mokgoatšana (University of Limpopo). 
religious symbols and symbolism that demonstrated and continue to demonstrate real originality in decorating their churches without imitating western art and aesthetics. This has amplified and demonstrated the African whirlwind energy and drive for inculturation ${ }^{1}$ in their attempt to make the gospel message truly African. Evidently, as observed by Baur (2009), after 2000 years of Christianity in Africa, the dynamics and dialectics of African Christianity today exhibit a Christianity that is visibly alive and healthy. Large numbers come together for liturgy, where men and women serve in a number of denominational and interdenominational ministries that build up both church and community, deriving inspiration from local leadership, hymns, drums, vernacular Bibles as well as admirable paintings and sculptures. With reference to Zimbabwe's long road to political freedom, McLaughlin (1996:13) posits that as early as the pre-independence era, inculturation attempts were visible - Shona hymns were composed with Shona melodies, ${ }^{2}$ local musical instruments (mbira, drums), and African Art and architecture were used in the construction of new churches such as one at Serima Mission.

Ever since the establishment of Serima Mission in the mid50s by Father John Groeber, several scholars have popularised the craft of Serima African School of iconography (Morton 2012; Plangger \& Diethelm 1977:1; Saint Mary's Mission 1962:7; Zhou 2017:54) to mention just but a few. To examine the role of iconography in African Christian liturgy, particularly at Serima Mission, both primary and secondary sources have been used. Alongside critical and valuable information on Serima Mission available in books and online, one of the authors carried out interviews at Serima Mission from the month of April to August 2018. Whilst most interviews were directed at Serima Mission parishioners, some questions, however, targeted non-Catholics from the neighbourhood who seemed to hold an unfavourable view with regard to the role of religious symbols and symbolism. Whilst the article demands that we examine the role of iconography in African Christian liturgy with particular focus on Serima Mission in the Catholic Diocese of Gweru in Central Zimbabwe, it is critical and academically creditable to begin by tracing the life and professional background of the towering figure of Fr John Groeber, the founder, and Father of Serima African School of iconography and to ground iconography within a theoretical framework that will assist us in our interpretation.

\section{Iconography and the paradox of semiology}

The arguments raised in this article can best be understood within the theories of semiotics. Semiology or semiotics is not

1.The term inculturation may as well be used interchangeably with terms and concepts such as indigenisation, Africanisation, contextualisation, acculturation, enculturation, concretisation, localisation and adaption (Chiromba 1989:3). Inculturation involves the meeting between the heart of the Gospel and the heart Inculturation involves the meeting between the heart of the Gospel and the heart
of African culture so that Christ becomes the principle of animation to generate a of African culture so that Christ becomes the principle of animation to generate a
new creation. Inculturation happens when the Gospel of Jesus comes to people new creation. Inculturation happens when the Gospel of Jesus comes to people
living in their own culture. The Gospel changes, purifies and enriches their culture (Amecea Pastoral Department 1995:26).

2.McLaughlin further underlined that many of the Shona hymns were, however, a few years later politicised and sung at all-night freedom rallies by ZANLA Forces. a single unified theory; however, it concerns itself with the use of signs and images to convey meaning. Several theorists, especially structuralist linguists such as Pierce, Saussure, and Umberto Eco have defined the scope and the use of signs to arrive at meaning. Most, argue that the relationship between the sign and the signified is arbitrary but contextual. It is the context that determines how we assign meaning. This contention is best explained in Jacques Derrida's concept of difference which explains that the meaning in a sign is continually delayed in the act of interpretation. This delay translated loosely into English, relates to a change of meaning in the interpretative context.

The article draws its methodological and theoretical frames from various semioticians who shaped the understanding of art history, as well as landscape design. The theory of semiotics is credited to two major theorists, Pierce and Ferdinand de Saussure, resulting in two major camps, American and French semiotics. Semiotics derived from the Greek word sêmeioun, meaning interpreting the sign or alternatively the sign itself, is understood as the theory of signs, the science of signs. Aiello (2020) makes this important description of semiotics:

... semiotics is indeed both a theory and a methodology that can be applied to a variety of 'texts', including novels, paintings, films, buildings, websites, and even clothing. The term 'text' refers to any semiotic object endowed with material or symbolic boundaries and structural autonomy, or where different parts all have a function in relation to a 'whole' and which can therefore be examined as a unit. (p. 368)

As a methodological design, semiotics allows the critic to examine sign within a sign system in order to arrive at a particular meaning. In our case, we shall examine the cultural context that produces the sign, and the context in which the sign is interpreted. Signs, therefore, find expression and meaning in cultural contexts which should be considered in the moment of interpretation.

Pierce identifies three kernels of semiotics, namely, an icon, index, and a symbol all providing a referential meaning, constituting the semiotic triangle; unlike the sign-signified dichotomy suggested by Saussure (Gatsou, Politis \& Zevgolis 2012:94). Ùjavári (2020) employs three levels of meaning to explain religious symbols, namely, semantic, syntactic, and pragmatics. In his explanation:

[S]emantics deals with the signification of signs (the representation or conveying of the meaning); syntactic involves combinations of signs, and pragmatics is that portion of semiotics that examines the origin, uses, and effects of signs in the situation in which they occur. (p. 18)

Panofsky's concepts of iconography and iconology come very close to the use of signs and icons in determining what to mean in art (Hasenmueller 1978). In his interpretation of meaning in art, Panofsky speaks of three levels of meaning, namely, primary (or natural) meaning, secondary (or conventional) meaning, and intrinsic meaning. Primary meaning relates to factual meaning, which is the identification 
of visual objects from experience, as well as the expressional meaning connected with sensitivity to the psychological understanding of the facts.

For Panofsky, the primary meaning is sensible, whilst the secondary meaning is intelligible. This mutual intelligibility of signs is a result of shared experiences, producing shared meanings. Panofsky's ideas about signifying gestures and signified messages help us to delve into the realm of signification, examining symbols as signs pregnant with meaning that require interpretation. We contend that the connection between signs and meaning is not a straightforward route, but complex. For this reason, the iconography of the Serima Mission is open to multiple interoperations which we acknowledge; however, meanings ascribed are also indicative of the religious and theological themes, and views connected with such iconography. This article considers visual iconography as a branch of semiotics, detailing both theory and methodology. It observes images, symbols, and icons as representations of real and imagined objects, subjects, and landscapes. These are examined against their socio-cultural milieus; in our case, these objects are located within African culture, thus allowing the pre-sensing and (re)positioning of African culture in the centre of the critical enterprise.

\section{Father John Groeber}

Father John Groeber's early life and professional background is largely documented by Plangger and Diethelm (1977:5-10), Morton (2012), and Zhou (2017:54), among many others. His early life, particularly his professional background is a prerequisite to the understanding of his impact in Zimbabwe as a clergyman of unprecedented artistic abilities. Never in the history of Catholicism in Zimbabwe has there been a clergyman so gifted in architecture and artistry as Father John Groeber. He was born in 1903 in Basel, Switzerland to a Christian family with limited resources. Because of the financial challenges and modest family background, John's academic career was disrupted before he completed high school. As a school dropout, at the age of 16 , he took his first job as an apprentice building draughtsman for an architectural firm, a profession that equipped him for six years with the basics of architecture and construction and further polished his innate talent and potential for technical drawing. As a draughtsman, he also had the chance to work on some famous building projects such as the Federal Charter Archive (Morton 2012).

Driven by an insatiable appetite to become a Catholic priest and a fisher of men (Mt 4:18-20), John Groeber later joined the Swiss Bethlehem Missionaries (SMB) in 1926. As underscored by Plangger and Diethelm (1977) and Zhou (2017:54-55), it was during this protracted period of training, spanning over 10 years that John completed his High School studies, thereby receiving formal education once more after several years of academic inactivity. After the completion of his priestly studies, possibly philosophy and theology, John was ordained a Catholic priest in 1936. As a young priest who was passionate and enthusiastic about spreading the gospel message through art, soon after his ordination to the priesthood in 1936, Fr John's superiors allowed him to enrol at Kunstgewerbeschule Lucerne, a famous educational centre that specialised in training teachers and students in the field of visual arts before they could be deployed for missionary work.

During his short stint at Kunstgewerbeschule Lucerne (1936-1939), John received thorough training in European art history. He also took the opportunity to study Romanesque painting and architecture even though he was recalled by his superiors before he could complete his degree. Haene (1966), however, posits that even though he was without a degree, Groeber possessed a vast knowledge in architecture, construction, and art. Armed with such skills that put him in a class of his own, Groeber was then capable of producing an architectural triumph that would define his life's work in spite of his poor background and marginal academic credentials and abilities (Plangger \& Diethelm 1977:5-10). Morton (2012) described Fr John Groeber as a highly introverted autodidact, a condition that could have possibly contributed to a display of his architectural genius.

\section{Missionary assignment to Rhodesia}

Equipped with a smattering of construction, architecture, and art training in his professional background as observed by Morton (2012), Fr John Groeber was posted as a missionary to Rhodesia (now Zimbabwe) in 1939, just on the eve of the Second World War (01 September 1939 - 02 September 1945). When Fr Groeber arrived in Zimbabwe, Bishop Chichester had already founded Chishawasha Regional seminary in 1936 in Salisbury (now Harare). By then, Bishop Chichester had thrown himself, heart and soul, into the creation of an African clergy, which he considered the most important work of his episcopate (Dachs \& Rea 1979:136). Chichester's long-range objective was to create a self-ministering church that would be ministered and served by purely sons and daughters of the soil at some stage.

In a paper presented at the Kevin Carroll Conference on African Christian Art on 06 October 2012, Morton hailed Fr John's workshop at Serima Mission and its impact on the Zimbabwean Stone Sculpture movement. She underscored that in his early years in Rhodesia, Fr Groeber was rather nomadic. For nearly a decade, he moved from one mission station to another, working on a number of building projects (Morton 2012). Zhou (2017:55) also underlined that in the period 1940 to 1946, Fr Groeber never stayed at one place for a long time but moved from one mission to another, a period during which he completed a total of six building projects. Some of the mission stations where Fr Groeber stayed before he moved to Serima include Chishawasha in Harare, Driefontein in the Midlands province, Silveira in Bikita District, St Joseph's in Chirumanzu, and Gokomere in Masvingo (formerly Fort Victoria). Wherever he went, in both churches and schools, Fr Groeber painted sets of murals portraying biblical scenes based on African designs, much to the delight of the local converts (Morton 2012). 
Thus, from 1939 to 1948, Fr Groeber showed that he was an ideal architect. Dachs and Rea (1979:138) documented that Fr Groeber made a beginning of his great work of art at the Regional Seminary in Salisbury. His artistic potential and genius is particularly noticeable in the arches in front of the seminary chapel. Upon the completion of his building projects at various mission stations, in 1946, Fr Groeber made a formal request to his superiors for the approval and authorisation to build and run his own mission that reflected his artistic genius and talent. For two years, his superiors seriously reflected and prayed about his request. After some serious pastoral and theological considerations, in 1948, his request was granted. He was then given a daunting task to develop Serima Mission in Gutu district, 'a mission which he so built his art school as to make it one of the best-known missions in the country today' (Dachs \& Rea 1979:152). Seemingly, his heart was restless until it rested at Serima Mission in 1948

\section{Serima mission and school of iconography (1948)}

Plangger and Diethelm (1977), Morton (2012), and Zhou (2017), among many others, concur that upon arriving at Serima Mission in 1948, Fr Groeber's missionary approach was impressive and methodical, employing some short, measurable, achievable, realistic and time-bound objectives and techniques to build his dream mission in the Serima reserves. Realising that there were no schools to provide education to the local people within the Serima reserves then, Fr Groeber's first objective was to establish a mission school to provide the academic needful. With the help he got from a couple of his SMB missionaries and local converts, by 1955, the Serima boarding school had been completed. When Fr Groeber realised his first objective, he then turned his attention and full energies on the construction of the church in 1956, largely through the assistance of about 15 male students from his newly established art workshop. Father Groeber's art workshop was popularly referred to as the Serima African School of iconography. By then, local craft production was practically extinct in the reserves that the Rhodesian settlers restricted their African subjects to (Morton 2012).

The contribution of Fr Groeber's art students in the construction of both the school and church was impressive and unprecedented. Names such as Gabriel Hatugari, Cornelius Manguma, Ernest Bhere,Nicholas Mukomberanwa, ${ }^{3}$ Joseph Ndandarika, ${ }^{4}$ Khumalo, and Sgango feature more prominently among Fr Groeber's most trusted students. As a man who possessed background abilities in architecture, construction, and art before he came to Zimbabwe, as has already been highlighted, Fr Groeber was passionate about

3.Mukomberanwa's early artworks of the mid-1970s to the early 1980 s espoused his patriotism and pride in his Zimbabwean heritage. This can be seen, particularly, in his numerous renditions of the national symbol of the Zimbabwe Bird which he sculpted in a variety of guises well into the 1990s (The Patriot, February 262015 ).

4.Whereas Joseph Ndandarika left Serima African School of iconography in 1959 Nicholas Mukomberanwa left a year later in 1960. It is documented that Cornelius Manguma later taught art and decorated much of the Serima church interior. the school of art and thus worked hard to develop the creative talents of these prominent first-generation artists in Zimbabwe. These local artists worked mainly in the afternoons, training in various fields such as drawing, patterning, pit firing, wood, and stone carving. In return, Fr Groeber gave them scholarships (Morton 2012). He was very particular about decorating the church interior. He only assigned his students to decorate the church interior when he was satisfied with their artworks and technical abilities. No second-class art was to be accepted for decorating the church interior. Inasmuch as they were at liberty to be as creative as possible, under the watchful eye of their most trusted patron, they were, however, forbidden to produce carvings for sale. By 1958, the church exterior was completed and the church interior followed, eight years later in 1966. The Diocese of Gwelo dedicated the Church to St Mary the Mother of God; hence the name St Mary's. Courtesy of Fr Groeber and his team of local artists, today, dominating the site at Serima Mission is the huge church with a steeple, decorated outside (at the back) with different soul daubs in the traditional Makaranga ${ }^{5}$ fashion (Zhou 2017:58). Whilst Serima church towers above all other buildings at Serima Mission, it is the church interior and exterior that deserve particular mention.

It should be emphasised from the beginning that Fr Groeber showed great artistry in ornamenting both the church interior and exterior, adapting the church structure to African culture and climate. In view of the fact that Fr Groeber's main objective was to spread Christianity through art, the Serima church interior was thus intended to create an African expression of Christianity, with numerous decorative wood and stone sculptures in African form. The church interior presents an expression of the power of African art, visual language, summation of the catholic faith, and the otherness and transcendental nature of the omniscient, omnipotent, and omnibenevolent Christian God, much to the appreciation of Fr Groeber's more than 1000 converts at Serima Mission then. Paintings of biblical scenes and stories that summarise Catholic faith are clearly visible from the entrance right up to the altar. Most icons commonly depict Christ, the Blessed Virgin Mary, saints, angels, and prophets although a lot more depict some outstanding biblical episodes. These include annunciation of Jesus (Lk 1:26-38), nativity (Lk 2:1-13), wise men from the East (Mt 2:1-12), baptism of Jesus (Mt 3:13-17), sermon on the mount (Mt 5-7), the Last Supper (Mk 14:22-25), the passion of Christ (Mt 26-27), resurrection (Jn 20:1-10) and ascension of Jesus into heaven (Mk 16:19-20), among many other biblical stories and episodes.

Describing Serima Mission exterior and interior art, Saint Mary's Mission (1962:7) remarked that Serima art is a combination of an 'almost Spanish style and elements of the

5.The Karanga (Makaranga) are a group of Shona speaking people in the southern part of Zimbabwe. The Shona dialectical groups comprise the Zezuru in the central part of Zimbabwe. The Shona dialectical groups comprise the Zezuru, in the centra part of the country, the Korekore in the North, the Karanga in the south, Manyika in the east, the Ndau in the south-east and the Kalanga in the south-west. Most of the Karangas live in the Mberengwa district in the Midlands Province. But there are several other groups in the neighbouring Zvishavane and Shurugwi districts in the Midlands provinces and Chivi and Zaka districts in the Masvingo province (Shoko 2007:501). 
medieval Romanesque church'. Arched doors and strip buttressing give the church an almost medieval touch. Plangger and Diethelm (1977) also underscored that the triangular apse with the consequent overall resembles a huge pair of shorts, with all church doors, altars, window frames and shrines having been made by Fr Groeber's students. Sultan (1999:11) cited by Zhou (2017) also adds that the wooden sculptures that decorate the Serima Church and school 'are striking in their simplicity, geometric structures, and expressionist feel, halfway between Roman sculpture and African art'. Summarising the same general picture at the magnificent Serima Mission, Fute (n.d.:par 1) thus remarked:

\begin{abstract}
... It is a medieval church and is one of the most amazing monuments in the country. Apart from the fact that the building was built in the spirit of European medieval architecture, it is above all the admirable paintings and sculptures that surprise the traveller...Y You must take time to admire the doors, the beams, and the furniture entirely carved by hand, the pillars with the appearance of totems, the sculptures of African angels, as well as the frescoes and bas-relief refracting episodes of the Bible. A very interesting little cultural detour. (n.p.)
\end{abstract}

From 1948 to 1968 , being guided by an insatiable appetite to spread the word of God through art, Fr Groeber thus introduced a unique dimension and model of evangelisation at Serima Mission, Gweru Diocese, and Zimbabwe Catholicism at large before he was transferred to Driefontein in 1968 at the age of 65 . Even though he initially rejected the transfer, citing old age, he, later accepted the new appointment and opened yet another art school at Driefontein Mission in 1972, shortly before he died in 1973. Ever since Fr Groeber's demise in 1973, Serima African school of iconography has become a subject of serious sustained academic research at both local and global levels. Of keen and particular interest is the role and place of religious icons and images in African Christian worship.

\section{The role of church art in African Christian liturgy}

Whilst the atmosphere at Serima Mission (particularly church interior) expresses an abridged episode of the Catholic faith and the uniqueness and transcendental nature of the omniscient, omnipotent, and omnibenevolent Christian God, the role of church art or church aesthetics in African Christian worship cannot be overemphasised.

The Catechism of the Catholic Church (1994: hereinafter CCC) is the deposit of the Catholic faith, including the belief in icon and image veneration. The Catholic Church stipulates that because the incarnation of the Son of God (Christ) has ushered in a new economy of images, it logically follows that the sacred image, the liturgical icon, principally represents Christ, for it cannot represent the invisible and incomprehensible God. Thus, fundamentally, Christian iconography expresses in images, the same Gospel messages that sacred scripture communicates by word. The Catholic Church thus further emphasises that all signs in the liturgical celebrations are, therefore related to Christ, as are sacred images of Mary the Mother of God and the saints. They all signify Christ who is glorified in them (CCC 1994:303).

In an interview conducted by one of the authors at Serima Mission to establish the role of iconography in Christian liturgy, particularly at Serima Mission, it was established that the role and function of innumerable sets of murals portraying biblical designs and patterns at Serima Mission are critical. Although Serima art has been described as a combination of an almost Spanish style and elements of medieval Romanesque (Saint Mary's Mission 1962), parishioners at Serima Mission strongly believe that Serima iconography, which is a blending of Christian iconography and African art, enhances the beauty of their church as a house of God and their house of prayer for decades. (Masango Muchena, interview, 20 August 2018). Thus, even though McLaughlin (1996) described Serima art as outstanding, Fute (n.d.:par 1) ranked Serima art as an interesting cultural detour in its own regard.

Besides enhancing the beauty of Serima Mission, taking full cognisance of the fact that Serima iconography is particularly rich with symbolism in its theology, it has been and continues to be instrumental in instructing the faithful in matters pertaining to the Christian (particularly Catholic) faith (Matapire Murenga, interview, 04 April 2018). In view of the fact that during Fr Groeber's long stint at Serima Mission (1948-1968), the majority of his parishioners were illiterate and Bibles were not easily available and affordable, visual catechesis was, therefore, critical. Thus, as Fr Groeber conducted his regular catechism classes, art and religious images were used as teaching aids, much to the appreciation of his largely illiterate Karanga parishioners. Pope Gregory 1 (c. 540-604), who is ranked and remembered as one of the four greatest fathers of the Church (alongside Ambrose (339-397) Augustine (354-430), and Jerome (347-240) is remembered by his remark that art is to some extent the book of the illiterate.

Apart from being used as teaching aids by catechists at Serima Mission, both exterior and interior Serima art was also critical in constantly reminding parishioners of their sacrosanct beliefs and practices as members of the one, holy, catholic and apostolic church (Makore Tapiwa, interview, 10 August 2018). As observed by Cavarnos (n.d.:par 10), Christians know many things about God, exemplary characters, and noble deeds of many holy personages but they tend to forget them as they preoccupy themselves with everyday matters and pursuits. Surrounded by icons, Christians do not fall asleep spiritually. They are constantly reminded and lifted up to the prototypes, to a higher level of consciousness of thought and feeling. They believe that prototypes such as Christ, Mary, prophets, saints, apostles, and martyrs do enjoy a higher level of being than ordinary Christians in their ordinary distracted everyday life. The symbolic and sacramental nature of icons in this regard is 
clearly spelt out. An icon is not an end in itself but simply a means, a symbol that carries Christians and believers well beyond itself. It is designed to lead devotees from the physical and psychophysical to the metaphysical and transcendental realities. In that regard, icons may be conceived as having a deductive function, from the horizontal to the vertical. Thus, traditionally, they have always served as sacramental, defined as sacred signs which bear a resemblance to the Sacraments ${ }^{6}$ (McIntosh 2020:par 3).

Closely connected to lifting Christians up to the prototypes as highlighted, icons also play a fundamental and foundational role in stirring Christians to imitate the virtues of their role models in faith (Manyara Muchaneta, interview, 20 April 2018). The same point is also echoed by Cavarnos (n.d.:par11) when he emphasised that the more holy personages are seen in icons, the more are the beholders lifted up to the memory of the prototypes. In the last analysis, the prototype is God who created men and women in his own image. The CCC (1994) rightly puts it:

The beauty of the images moves me to contemplation, as a meadow delights the eyes and subtly infuses the soul with the glory of God. Similarly, the contemplation of sacred icons, united with a meditation on the Word of God and the singing of liturgical hymns, enters into the harmony of the signs of celebration so that the mystery celebrated is imprinted in the heart's memory and is then expressed in the new life of the faithful. (p. 304)

Thus, in order to constantly remind them of the deeds of their personages, a number of parishioners at Serima Mission have assumed new names at baptism as recommended by the church. Names such as Mary, Joseph, Peter, Elizabeth, Matthew, and John as opposed to traditional Shona names feature more prominently (Tanaka Mawire, interview, 15 August 2018). The Catholic Church often emphasises that at baptism, the new convert receives a new name in the church. This could be the name of a saint or a disciple who has lived a life of exemplary fidelity to the Lord. That particular personal patron saint provides a model for charity and the church is assured of his or her intercession. The baptismal name can also express a Christian mystery or virtue. Thus, parents, sponsors, and the pastor are urged to make sure that a name is not given which is foreign to Christian sentiment (Canon 855).

It is critical to underline that religious icons are intended to transform the character of believers, their whole being in order to sanctify them. One interviewee remarked that when he looks at an icon during public worship, particularly the celebration of the Eucharist, in essence, it is not him looking at the icon but rather the icon looking at him and probably asking him some personal moral questions. By doing so, he is forced to change his character. He is stirred morally and

6.The sacraments are efficacious signs of grace, instituted by Christ and entrusted to the church, by which divine life is dispensed to us. The visible rites by which the sacraments are celebrated signify and make present the graces proper to each (CCC 1994:26). The Can those who recen (ccc 1994:296). The Catholic Church believes in seven sacraments, namely, Baptism, Confirmation, Eucharist, Penance, Ordination, Matrimony, and Anointing of the Sick. spiritually. Consequently, he becomes like that which he habitually contemplates (Masango Machawira, interview, 10 April 2018). Thus, the primary function of an icon is liturgical. It is a means of worship and veneration. As observed by Cavarnos (n.d.:par 15), like sacred hymns and music, an icon is used as a means of worshipping God and venerating his saints. The same point was echoed by yet another interviewee who emphasised that when she participates in a liturgical celebration, particularly the Eucharist, all her five senses will have a chance to actively participate. Surrounded by religious icons and images that she could see and touch, enjoying a strong sweet smell of incense during Holy Mass, listening to the sound of church bells that often signify critical stages of the holy celebration and, finally receiving and tasting Holy Communion, a well-prepared devotee makes an encounter with the living and transcendental God without fail (Tanaka Mawire, interview, 15 August 2018).

Whilst Serima iconography served and continues to serve as a means of spreading the Gospel as Fr Groeber's primary focus and the main objective, it had several other functions within and beyond Zimbabwe's borders. Thus, Zhou (2017) acknowledged and appreciated the fundamental and foundational importance of Christian art (particularly Serima art) in the rise of prominent first-generation artists in Zimbabwe such as Mukomeranwa, Ndandarika, and Khumalo, among many others. These personalities became popular, not just with Church art but also in the secular stone sculpture industry. Thus, the church had an impact on the education and training of many of Africa's most influential artists. Mission derived Christian art was also central to the development of modern art in Southern African Art History as a discipline in the 1960s as underscored by Morton (2012).

Even though Serima Mission is perhaps the most popular in iconography with innumerable sets of wood and stone carvings portraying mostly religious scenes based on African designs and patterns as already mentioned, the practice of venerating icons and religious images is not peculiar to Serima Mission or the Roman Catholic Church. When Christianity was established in Zimbabwe about a century ago, resident local cultures had their own religion whose essence was enshrined in art, symbols, music, dance, and proverbs, among many other forms. Thus, an understanding of the intricacy and complexity of the African traditional worldview is critical and foundational in any discussion about religious symbols and symbolism. From a typical African contextual landscape, the fact that the African traditional religion is complex and elaborate cannot, therefore, be denied. The belief in icons and images is, however, a common phenomenon, particularly within the Shona, particularly Karanga traditional spirit worldview that largely dominates the area around Serima Mission. Fundamentally, all the vaKaranga people around Serima Mission are African by culture and Christian by choice. For that reason, the influence of the resident Karanga culture and religion in the role and impact of religious art may not be overstated. 


\section{Art and symbols in African traditional religion}

Mbiti (1975:19), Cox (1992:97), and Omatseye (2010:529), among many other scholars, examined the role of art and symbols in African traditional religion. Inasmuch as African traditional religion is found in various forms such as rituals, ceremonies, festivals, shrines, sacred places, music and dance, proverbs, riddles, wise sayings, names of people, myths, and legends, it is even more pronounced in religious objects, art and symbols. Thus, arts and crafts are part of the African heritage and they express some deep religious ideas. In most cases, African art is found on wood, stools, calabashes, stones, sticks, pots, handicrafts, domestic animals, and human bodies. It is also expressed in the form of masks and carvings on wood, ivory, and stone (Mbiti 1975:19-27).

The interactive relationship between art and religion in the African context remains remarkably understudied and misunderstood as observed by Hackett (1994). Cox (1992:99) talks of presentational art and representational art in any form of religion. Hall, Pilgrim and Cavanagh (1986:78) refer to presentational art in which it immediately brings the believer into the presence of the sacred or evokes that presence. They further reveal that art that tells a story, offers a message, or conveys a religious truth is representational. Representational symbols could be said to perform a more didactic or teaching function as the tradition or teaching is passed on throughout history. Following the same logic, it is critical to underline that African art is pregnant with both presentational and representational art, a traditional art that for centuries has played a pivotal role in providing critical points of entry into the conceptual worlds of the African people. Omatseye (2010) observed that African arts stem from their themes of symbolism, functionalism, and utilitarianism, which describe African art as quite multifunctional. In Africa, he argues, by virtue of their belief system, their spiritual practices have led to the creation of new artistic imageries. This is in the sense that their various artistic traditions are drawn upon as sources of inspiration. Significantly, indigenous African religions have had a greater influence on art objects, statues, masks, or other forms for use in rituals and worship. Omatseye further highlights that essentially, figures, statues, and shrine arts, and verbal and non-verbal arts in most African cultures are largely functional. These images have religio-metaphysical themes which serve as the focal point of power, which then links the African's physical world to his beliefs on his essence and existence. Indeed, African art reflects images of ancestral spirits and pantheons of indigenous gods and goddesses. Through carved images, the African can appease malevolent spirits (Eyo 1977).

The desire of Africans to connect with their spiritual hierarchy is activated and mediated through sculptural objects and symbolism. Religion and worship thus open another avenue through which art plays a role in traditional cultural patterns. Alongside its potential to disseminate information, propagating the African traditional religion, African cultural heritage is preserved by art and symbols (Gyegwe, Anaso \& Haruna 2016:33). In view of the fact that art objects, whether sculpted figures, textiles, or paintings are generally enjoyed and critiqued and used by communities or groups, rather than being the prerogative of individuals alone (Hackett 1994), the fact that Serima artists could have been influenced by their traditional world view cannot, therefore, be denied.

\section{Religious images in the Old Testament}

The fact that icons and images have their deep roots in Scripture, particularly the Old Testament cannot be overstated. In the Old Testament, religious images could be made from copper, silver, or gold. Graven images could be carved from stone or wood. In most cases, wooden images could be overlaid with some precious metals (Is 40:19; 41:6-7, 44:12-17). The New Bible Dictionary (1996:408-410) traced the tradition of honourable reverence of sacred objects back to the ancient Near East and the mosaic people who venerated on all hands the tabernacle, an image that represented Yahweh Himself. The New Bible Dictionary emphasised that throughout the ancient Near East, numerous deities were to be found in temples and other holy places such as open-air shrines. Private houses also contained a niche where the image of the protective deity of the household stood. In most cases, images were either in human form (anthropomorphic) or in animal form (theriomorphic) in some other cases, particularly in Egypt.

In theriomorphic cases, the form of the image would represent some prominent characteristics of a particular deity or deities. Thus, an image of a bull portrayed the god's power of fertility. The image was, however, not primarily intended as a visual representation of the deity, but as a dwelling place of the spirit of the deity enabling the god to be physically present in many different places simultaneously. Thus, worshippers praying before an image, for example, would not necessarily accept that their prayers were being offered to the figure of wood or metal before them but would probably have regarded the image as a projection or embodiment of the deity. It is critical, however, to emphasise that those in Israel who denied any reality to the deity represented by the image rigorously maintained that the worshippers of foreign deities paid homage to mere wood and stone (New Bible Dictionary 1996).

A comprehensive survey of the history of the Old Testament reveals that the chequered history of the Israelites is occupied with images of foreign gods. Although the making and worshipping of images are largely forbidden in the Pentateuch (Ex 20:4-5) and condemned by the prophets (Jr 10:3-5; Hs 11:2), their use in Israel throughout pre-exilic times was common (Jdg 6:25; $1 \mathrm{Ki} \mathrm{11:5-8;} \mathrm{16:31-33),} \mathrm{even} \mathrm{at}$ times within the Temple itself (2 Ki 21:3-5, 7). Images of Yahweh were also visible and common among Israelites. 
Standing stones erected by the Patriarchs (Gn 28:18, 22; 35::14) were perhaps originally regarded as images (similarly the sacred trees of Genesis 21:33) but were later forbidden (Dt 16:21) or better still reinterpreted as merely commemorative objects (Gn 31:45-50 Jos 4:4-9). Later, images of Yahweh were denounced by pure Yahwists: the golden calf at Sinai (Ex 32:1-8, the image made by Gideon (Jdg 8:26-27), the golden calves at Dan and Bethel (1 Ki 12:28-30) as well as the calf of Samaria (Hs 8:6). This culture of belief in icons and images was unbroken right up to the coming of Christ and beyond. Thus, the New Testament and the tradition of the Christian church built on the foundation laid in by the Old Testament.

\section{Religious icons in the history of Christianity}

The veneration and reverence of holy icons by Christians are deeply rooted in the sacred tradition of Christianity. Frontline writers on Christian art and images (Algermissen 1957:302; Ancient Faith Ministries 2004; David 2014, among others) do concur that inasmuch as Christian churches to date are populated with icons and images, veneration of icons does not go back to the earliest days of the church. A quick scan through Christian history and thought reveals that images (art) and icons (venerated) were a later gradual development, only officially adopted centuries after the first Christians. It is critical to underline that in the earliest centuries of Christianity, there was little or no art simply because the Christian religion had not yet been legalised and there were no monumental churches during that time.

David (2014) posits that the first recognisable Christian art appeared in the 3rd century in motifs and patterns seemingly borrowed from common non-Christian art and appropriated for Christian use, as well as in simple depictions of some Old and New Testament subjects such as oil lamps mostly put in catacombs and in churches. With the conversion of the upper class, particularly Emperor Constantine in the 4th century, we then witness a critical paradigm shift and a turning point that laid the foundations for the eventual change in attitude from simple art to venerable icons. When persecutions officially ended in 311 and Christianity was legalised by Constantine through the Edict of Milan, elaborate churches were built under imperial patronage. Thereafter, portraits of Jesus, Mary, martyrs, and saints appeared in churches. They became more sophisticated and elaborate during this period. Images of saints were thus commemorative and protective. With the veneration of martyrs in the catacombs, the cult of relics as healing and intercessory powers of dead saints also spread throughout the empire. By the 4th century, it was slowly becoming clear that the new religion (Christianity) was too widespread, too entrenched, and too popular to be destroyed (Brockman \& Pescantini 1991:30). Thus, Christian art and icons soon stuck roots in Christian popular religiosity as the church developed a form of art peculiar to its needs for centuries until the use of icons was vehemently criticised and repudiated in the 8 th century.
The 8th-century iconoclast controversy (730-843) ushered in a bloody and dark era for the Christian church. During the 8th century, a powerful anti-icon movement that vowed to smash all icons and cleanse the church of heresy, superstition, and exaggerated spirituality emerged from within the church itself. As underscored by Franzen (1969:152), the iconoclasts argued that any portrayal of the incarnate God should include his double nature (divine and human), and because the divine nature cannot be pictorially presented, any solely human presentation would, therefore, be heretical. Any picture of Christ was thus regarded not just as dangerous but suspect of heresy. They also argued that because the common people tended to give all images (including those of Mary and Saints) a superstitious veneration, it would be better, therefore, to suppress images and the worship of images. They argued that icons were a late innovation in mainstream Christianity, and therefore should be rejected and repudiated with all force and might.

Franzen (1969:152) further highlights that under Emperor Constantine V (741-775), iconoclasm reached its peak. When he called the Council of Hieria (754) that was attended by 338 bishops, Constantine condemned the making and veneration of icons and ordered the destruction of all religious pictures (Ancient Faith Ministries 2004). Consequently, there were bloody riots, persecutions, especially of monks, who in some areas were almost entirely exterminated. The period became known as the decade of blood. For championing this dark era in the history of Christianity, Constantine V is to date regarded as the most rigorous critic of icons. After more than a century of persecution of pro-icon Christians, normalcy returned in the 9th century when a new Emperor, Empress Irene (780-802) came into power. As a strong supporter of icons, Irene did not hesitate to make immediate drastic changes when she assumed office. Shortly after coming into office, she restored image worship and convened the Second Council of Nicaea (787) which declared that images deserved reverence but not adoration which was because of God alone. The Council declared:

\footnotetext{
... the honour given to the picture reflects the honour given to the model. The value of the holy picture, of the icons, rests not in itself, but in its reference to the portrayed saint or to Christ. Whoever venerates a picture, honours the one who was painted. (Franzen 1969:152)
}

Thus, with reign change, the victory of iconoclasts became temporal. The victory of image veneration was restored and those who refused to venerate icons were cursed and anathematised in the official declarations of the church. Following the restoration of icon veneration, Christian art perhaps reached its zenith during the Middle Ages. Franzen (1969:112) argues that, as a whole, the High Middle Ages was a great and exciting time that found elevated expression in the wonderful works of Romanesque and Gothic art. In the monasteries, for example, Christian art and culture experienced a new flowering. During this period, Church building and book art reached their height, particularly in the impressive use of symbols. Brockman and Pescantini 
(1991:81) also add that the Romanesque church was massive and solid stone with lavish decorations, paintings, and lively tapestries in bright colours. Centuries later, throughout the world, the visibility of the influence of Romanesque art on several churches cannot be overemphasised. As underlined in earlier segments, Fr John Groeber, a missionary who founded Serima Mission art which happens to be the centre of this ensuing discussion was also given the opportunity to study Romanesque art before he was posted to Rhodesia (now Zimbabwe) for missionary work. Thus, several scholars who popularised Serima Mission iconography have categorised Serima Mission Church as a medieval church built in the spirit of European medieval architecture.

\section{A critical appraisal of icons}

Although the icon and image veneration within Christianity may have their roots deep into the Old Testament, the controversy that surrounds the role and source of Christian art still rages on. Tracing the history of icons in the Christian religion, Ancient Faith Ministries (2004:par4) presents two theories that try to account for the origin of icon veneration within the Christian religion. Whilst non-orthodox writings view icons as the Hellenising and paganising of Christianity, orthodox scholars see icons not as Hellenising or paganising of Christianity but rather as a Christianising of paganism. Art historians have also considered the first Christian art in the 4 th century simply as an aspect of Roman art of the time, and the elaboration of Christian art under Emperor Constantine as a continuation in Christian dress of more classical aspects of Roman art (David 2014).

Following the same logic, non-orthodox writers have repeatedly referred to church Fathers who vehemently condemned church images. These include: Origen (186-255), Tertullian (160-240), Eusebius (265-399) and Clement of Alexandria (150-216). Centuries after the condemnation of icons by the church Fathers, prominent reformers such as John Calvin (1509-1564), Ulrich Zwingli (1484-1531), and Martin Luther (1483-1546) also condemned the use of icons in Christian liturgy and worship. When Calvin considered that whatever Christians learn from God in images as futile, Zwingli was convinced that images are unable to communicate the true Christ to humanity. Similarly, Luther considered the matter of paintings and sculpture as having relative unimportance (Ancient Faith Ministries 2004).

From a local perspective, although Serima icons have received unprecedented popularity from both Catholics and non-Catholics, conservatives from certain Christian quarters have also criticised Fr Groeber's talent at Serima Mission. They have a strong feeling that there should not be any paintings in churches. They argue that putting images and icons in churches is tantamount to depicting that which is honoured in worship (Linaster Gomba, interview, 20 August 2018). The same critics also argue that even though Fr Groeber gave his art students considerable leeway and liberty in designing their own images in their own ways, a handful of Serima Mission art is exaggerated, thereby losing its original intended Christian teaching. By and large, some Serima carvings, with their mask-like faces, immense heads, and oversized hands which suggest the importance of the human mind and its powers of creativity (Zhou 2017), may not provide an entry point into the essence of the Christian religion. For that reason, one anonymous priest from the same Diocese of Gweru jokingly referred to Serima art, particularly in the church exterior, as resembling 'goblins' devoid of any religious meaning (Priest anonymous, interview, 20 April 2018). As emphasised by Zhou (2017), inasmuch as Fr Groeber did not want his students to mimic western modernism in their art, they ended up mimicking their patron instead, thereby exposing their talent to public scrutiny.

\section{Conclusion}

The article has examined the role of iconography in African Christian liturgy with a particular focus on Serima Mission art in Zimbabwe. Courtesy of Fr Groeber's vision and love for African art, Serima Mission is today considered to be one of Zimbabwe's architectural masterpieces, featuring a unique design combined with hundreds of carvings, murals, and ecclesiastical artworks that merge a coherent statement of Africanised Catholicism (Zhou 2017). The article has established that icons are at the centre of Christian liturgy among Serima Mission devotees in a number of ways. Firstly, they enhance the beauty of Serima Mission Church. Secondly, they instruct parishioners in matters that pertain to the Christian faith when they are used as teaching aids. Thirdly, they remind Christians of their Catholic faith and lift them to a higher level of consciousness when they reflect upon the deeds of their many holy personages. Fourthly, icons thus constantly motivate Christians to imitate the life of their fallen heroes and heroines of Christianity and by doing so, they are compelled to change their characters and gradually transform their lives. Even in the circular world, religious symbols have been the cause of victories in wars. Whilst icons are spiritually meritorious in a number of ways, several critics have, however, maintained a cautious and seemingly disengaged approach to the veneration and kissing of icons and images. In their religious ignorance, as observed by Algermissen (1957:640), most Christians believe largely in mysterious, supernatural powers possessed by their icons. They do not only venerate in them the saints that they represent but occasionally they use icons and images as amulets and curatives against dangers and sicknesses. By doing so, religious formalism, superstition, and exaggerated spirituality may become the order of the day if icon veneration is not constantly regulated and moderated.

\section{Acknowledgements Competing interests}

The authors declare that they have no financial or personal relationships that may have inappropriately influenced them in writing this article. 


\section{Authors' contributions}

Both the authors contributed equally towards this article.

\section{Ethical considerations}

The participants consented to be part of the research project, and indicated that pseudo names be used in the article.

\section{Funding information}

This research received no specific grant from any funding agency in the public, commercial, or not-for-profit sectors.

\section{Data availability}

Data sharing is not applicable to this article as no new data were created or analysed in this study.

\section{Disclaimer}

The views and opinions expressed in this article are those of the authors and do not necessarily reflect the official policy or position of any affiliated agency of the author.

\section{References}

Aiello, G., 2020, 'Visual semiotics: Key concepts and new directions', in L. Pauwels \& D. Mannay (eds.), The SAGE handbook of visual research methods, pp. 367-380, SAGE Publications, Inc, London.

Algermissen, K., 1957, Christian denominations, Herder Book Company, London.

Amecea Pastoral Department, 1995, The African synod comes home: A simplified text, Pauline Publications, Nairobi.

Ancient Faith Ministries, 2004, History of icons, viewed 20 March 2021, from https:// www.ancientfaith.com/podcasts/ourlife/history_of_icons.

Baur, J., 2009, 2000 years of Christianity in Africa: An African church history, 2nd edn., Pauline Publications, Nairobi.

Brockman, N. \& Pescantini, U., 1991, A history of the Catholic Church, St Paul Publications, Nairobi.

Catholic Church, 1994, The Catechism of the Catholic Church, Pauline Publications, Nairobi.

Cavarnos, C., n.d., 'The functions of icons', viewed 22 March 2021, from http:// orthodoxinfo.com/general/icon_function.aspx.

Chiromba, F.E., 1989, Evangelisation and inculturation, Mambo Press, Gweru.

Cox, J.L., 1992, Expressing the sacred: An introduction to the phenomenology of religion, University of Zimbabwe Publications, Harare.

Dachs, A.J. \& Rea, W.F., 1979, The Catholic Church and Zimbabwe, Mambo Press, Gweru.
David, 2014, 'When did Christian icons begin: Icons and their interpretation', viewed 15 March 2021, from https://russianicons.wordpress.com/2014/08/19/whendid-christian-icons-begin/.

Eliade, M., 1957, The sacred and the profane: The nature of religion, Harper \& Row, New York, NY.

Eyo, E., 1977, Two thousand years Nigerian art, Federal Department of Antiquities, Logos.

Franzen, A., 1969, A concise history of the church, Burns and Oates, New York, NY.

Fute, P., n.d., Serima mission, viewed 20 March 2021, from https://www.petitfute. co.uk/v60972-masvingo/c1173-visites-points-d-interet/c925-religieux/533073serima-mission.html.

Gatsou, C., Politis, A. \& Zevgolis, D., 2012, 'The importance of mobile interface icons on user interaction', International Journal of Computer Science and Applications 9(3), 92-107.

Gyegwe, A.G., Anaso, K. \& Haruna, C., 2016, 'The role of art in traditional cultural patterns', Arts and Design Studies 39, 31-34.

Hackett, R.I.J., 1994, 'Art and religion in Africa: Some observations and reflections', Journal of Religion in Africa 24(4), 294-308. https://doi.org/10.2307/1581338

Haene, A., 1966, 'Bishop's speech on the official opening of Serima chapel', in Gwelo (now Gweru) Correspondence File: Gweru Diocese, Serima Chapel, Gwelo.

Hall, T.W., Pilgrim, R.B. \& Cavanagh, R.R., 1986, Religion: An introduction, Harper and Row, San Francisco, CA.

Hasenmueller, C., 1978, 'Panofsky, iconography, and semiotics', The Journal of Aesthetics and Art Criticism, Critical Interpretation 36(3), 289-301, 289-301. https://doi.org/10.2307/430439

Mbiti, J.S., 1975, An introduction to African religion, Heinemann Educational Books, London.

McIntosh, A., 2020, 'The importance of iconography in Catholic Catechism', viewed 20 March 2021, from https://medium.com/catholicism-coffee/the-importance-oficonography-in-catholic-catechesis-catholicismcoffee-a926b075eac0.

McLaughlin, J., 1996, On the frontline: Catholic missions in Zimbabwe's liberation war, Baobab Books, Harare.

Morton, E., 2012, 'Father John Groeber's Workshop at Serima Mission and its impact on the Zimbabwe Stone Sculpture Movement', Paper presented at Kevin Carrol Conference on African Art, viewed 15 February 2021, from https://www. academia.edu/6779301/Father_John_Grobers_Workshop_at_Serima_Mission.

Omatseye, B.O.J., 2010, 'An appraisal of religious art and symbolic beliefs in the traditional African context', African Research Review 3(2), 529-544. https://doi. org/10.4314/afrrev.v4i2.58370

Plangger, A.B. \& Diethelm, M., 1977, Serima: Towards an African expression of Christian belief, Mambo Press, Gweru.

Saint Mary's Mission, 1962, Serima new art from African mission school: Skilled woodcarvers from Serima, NAZ, Masvingo.

Sarpong, P.K., 1985, 'Christianity and the symbol of unity in Africa', African Christian Studies 1(1), 4-12.

Shoko, T., 2007, 'Karanga traditional medicine and healing', African Journal of Traditional, Contemporary and Alternative Medicines 4(4), 501-509. https://do org/10.4314/ajtcam.v4i4.31244

Sultan, O., 1999, Life in stone: Zimbabwean Sculpture - The birth of contemporary art form, Baobab Books, Harare.

Wood, D.R.W. (ed.), 1996, New Bible dictionary, InterVarsity Press, Leicester.

Ùjavári, E., 2020, 'Religious symbols from the point of view of visual semiotics', The International Journal of Religion and Spirituality in Society 10(3), 17-26. https:// doi.org/10.18848/2154-8633/CGP/v10i03/17-26

Zhou, G., 2017, 'Missionaries' impact on the formation of modern art in Zimbabwe: A case study of Cyrene and Serima art workshops', Unpublished Master of Arts in History, University of South Africa. 